\title{
Institute doomed by loss of interest in basics
}

\section{David Cyranoski, Tokyo}

Eighteen years ago, it was a shining example of industry-sponsored science in Japan. But the Biomolecular Engineering Research Institute (BERI) in Osaka is to close next year, despite its scientific success.

The institute's plight reflects the wider fate of industry-sponsored science in Japan over the past 20 years. The once bountiful well of private-sector support for basic research has dried up, as grand corporate ambitions have shrunk in more austere and uncertain times.

Founded in 1986 as the Protein Engineering Research Institute, it was funded by the industry ministry and 18 companies. Its mission was to develop basic science that would underpin drug development. It now has an annual budget of $¥ 1.1$ billion (US $\$ 10$ million) and some 70 researchers.

Over the years BERI, as it became in 1995, has notched up important findings, particularly in the analysis of protein structures such as the glutamate receptor, which plays an important role in the nervous system (N. Kunishima et al. Nature 407, 971-977; 2000). "BERI researchers put out outstanding papers one after the other," says Shigeyuki
Yokoyama, director of the protein group at the Genomic Sciences Center in Yokohama. "They really led Japan in the early days of protein structure analysis.”

But in April, the institute's board of trustees, which includes representatives of the remaining nine companies that provide $30 \%$ of BERI's funding, decided to drop their support. Chairman Tadashi Hirata, chief executive of drug company Kyowa Hakko, refused to comment on the reasons for the decision.

"BERI has been very productive," says Mitsuru Takeshita, head of the biotechnology division in the economic ministry's New Energy and Industrial Technology Development Organization, which provides the other 70\%. "The problem is not whether BERI has been putting out results - which it has. Rather it is an internal organizational problem. The closing is very regrettable."

The institute's director, Kosuke Morikawa, says that BERI is closing because the gap between scientific discovery and industrial application is too large for sponsors to justify the cost. "From a research perspective we have been extremely successful and we have also trained many of the leaders of industrial science," says Morikawa. "But the companies have not retained much interest."

BERI's method of studying proteins oneby-one is also out of step with the move towards industrial-scale approaches such as the Protein 3000 project, Japan's effort to solve the structure of 3,000 molecules. "Groups around the world are finding that a bigger scale is better," says Yokoyama, whose group is leading the project.

Morikawa says he has courted patrons who might be able to support the institute, but so far has had no success. When he asked Hirata what to do, he says he was told to relaunch BERI as a small business. "I don't have the connections or knowledge to do that," he points out.

BERI's researchers may struggle to find employment at a time when Japan is trying to introduce more intense competition, with greater emphasis on industrial involvement in basic research (see Nature 429, 207-221;2004). Judging from the experience of BERI, which Morikawa envisioned as a model for such involvement, it will be a challenge for research institutions to meet these goals.

\section{Flying labs aim to track pollution across the Atlantic}

\section{Amanda Haag, London}

Scientists from North America and Europe took to the skies this week to track the movement of giant masses of polluted air.

During the six-week study, a tag team of five aircraft will follow parcels of air pollution as they travel from the east coast of the United States over the Atlantic towards Europe. An international team of some 100 scientists will pick apart the collected data.

Their mission: to understand the chemical interactions that take place as ozone-forming pollutants from factory smokestacks and car exhausts in the United States hitch a ride to Europe on prevailing winds - a journey that takes about four days.

The International Consortium for Atmospheric Research on Transport and Transformation (ICARTT) is launching the project to discover how atmospheric pollutants such as aerosols, free radicals and ozone behave chemically as they are transported from one continent to the next - and how they affect climate change and health issues.

The pollution that the researchers are

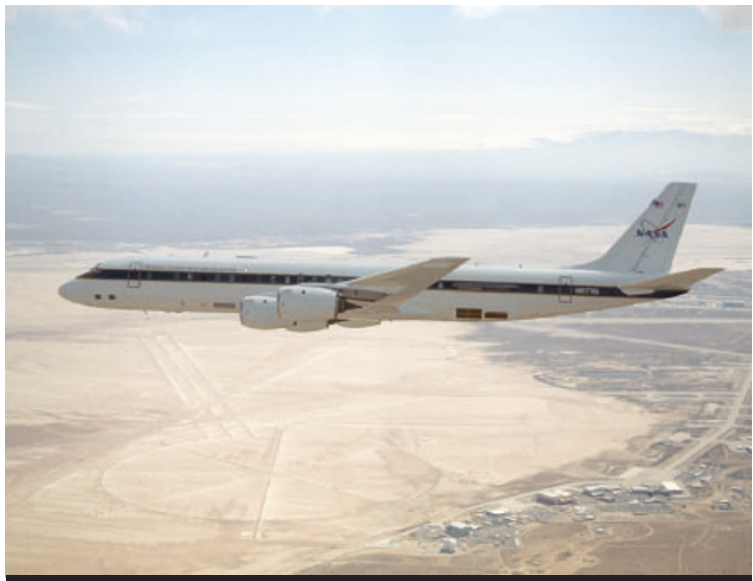

Plane truth: NASA's DC-8 forms part of a fact-finding fleet.

constituents of the invisible cloud, using weather forecasts, models and measurements to stay on track.

Similarly equipped planes have been used in the past to study small sections of the journey, but no sustained mission has successfully tracked the pollution right across the Atlantic.

Satellites have been used to monitor air transport over the Atlantic, but cannot be used to pick up on the details of the chemistry.

The multimillion-dollar study may one day help to shape global atmospheric policies, according to the team behind the project. Pollution isn't just a local problem,

studying builds up over an area covering New York, Washington DC and Boston during periods of still weather throughout the year. When the weather changes, this mass of air moves from the lower part of the atmosphere to the upper atmosphere. Winds then push the air mass over to Europe. The lump tends to break up as it crosses the Atlantic, but scientists hope to track at least one parcel of pollution that holds together.

The aircraft will measure the size of aerosol particles and the chemical says its lead UK scientist, Alastair Lewis, an atmospheric chemist from the University of Leeds. Dust blows from Africa to North America, and Europe's smog may be caused in part by pollutants from the United States.

During the 2003 summer heatwave, there were about 2,000 more deaths than usual in Britain, some $21-38 \%$ of which were attributable to heightened atmospheric pollution (J. R. Stedman Atmos. Environ. 38, 1087-1090; 2004). "Disentangling where it came from is very tricky," says Lewis. 